\title{
"Plain packaging" regulations for tobacco products: the impact of standardizing the color and design of cigarette packs
}

\author{
David Hammond, PhD. ${ }^{(1)}$
}

\author{
Hammond D. \\ "Plain packaging" regulations for tobacco products: \\ the impact of standardizing the color \\ and design of cigarette packs. \\ Salud Publica Mex 2010;52 suppl 2:S226-S232.
}

\begin{abstract}
Tobacco packaging and labeling policies have emerged as prominent and cost-effective tobacco control measures. Although packaging policies have primarily focused on health warnings, there is growing recognition of the importance of packaging as a marketing tool for the tobacco industry. The current paper reviews evidence on the potential impact of standardizing the color and design of tobacco packages -so called "plain" packaging. The evidence indicates three primary benefits of plain packaging: increasing the effectiveness of health warnings, reducing false health beliefs about cigarettes, and reducing brand appeal especially among youth and young adults. Overall, the research to date suggests that "plain" packaging regulations would be an effective tobacco control measure, particularly in jurisdictions with comprehensive restrictions on other forms of marketing.
\end{abstract}

Keywords: smoking; tobacco; package; plain; policy

\author{
Hammond D. \\ Regulaciones de "empaquetado sencillo" para productos \\ de tabaco: el impacto de la estandarizacion en diseño \\ y color en los paquetes de cigarrillos. \\ Salud Publica Mex 2010;52 supl 2:S226-S232.
}

\section{Resumen}

La política pública del empaquetado y etiquetado de productos de tabaco ha llegado a ser una forma costo-efectiva y significativa para el control del tabaco.Aunque las políticas públicas de empaquetado se han enfocado principalmente en advertencias sanitarias, el reconocimiento de la importancia del empaquetado como herramienta mercadológica ha crecido considerablemente. El presente artículo analiza la evidencia del impacto potencial de estandarizar el empaquetado de productos de tabaco -en color y diseño-, el llamado "empaquetado sencillo". La evidencia indica tres beneficios principales del empaquetado sencillo:mayor efectividad de las advertencias sanitarias; reducción de creencias falsas sobre cigarrillos y salud; y reducción de la preferencia por ciertas marcas, especialmente entre jovenes y jóvenes adultos. En general, los estudios hasta la fecha sugieren que el empaquetado sencillo sería una medida efectiva de control del tabaco, particularmente en jurisdicciones con restricciones amplias sobre otras formas de mercadotecnia.

Palabras clave: tabaquismo; tabaco; empaque; sencillo; política

(I) Department of Health Studies \& Gerontology, University of Waterloo. Ontario, Canada.

Accepted on: March 22, 2010

Address reprint requests to: David Hammond. Department of Health Studies \& Gerontology; University of Waterloo. 200 University Avenue West, Waterloo, Ontario, N2L 3G I, Canada.

E-mail:dhammond@uwaterloo.ca 
$\mathrm{T}_{\mathrm{b}}$ obacco packaging and labeling policies have rapidly become among the most prominent and cost-effective tobacco control measures. Packaging regulations comprise three primary areas: health warning messages, disclosure of product emission and constituent information, and removal of misleading and deceptive information. ${ }^{1}$ The current paper focuses on the removal of color and brand imagery of packages, commonly referred to as "plain" packaging.

\section{Current policy and regulatory developments}

International guidelines under Article 11 of the World Health Organization's Framework Convention on Tobacco Control (FCTC) — the world's first public health treaty-state that:

“...tobacco product packaging and labelling [shall] not promote a tobacco product by any means that are false, misleading, deceptive or likely to create an erroneous impression including any term, descriptor, trademark, figurative or any other sign that directly or indirectly creates the false impression that a particular tobacco product is less harmful than other tobacco products." ${ }^{2}$

To date, more than 50 countries have prohibited the terms "light," "mild," and "low tar." The list of prohibited terms has been expanded in countries such as Malaysia, to include: "cool", "extra", "low tar", "special", "full flavor", "premium", "rich", "famous", "slim", and "grade A." Elaborated guidelines for implementing Article 11 of the FCTC explicitly address plain packaging: "Parties should consider adopting measures to restrict or prohibit the use of logos, colors, brand images or promotional information on packaging other than brand names and product names displayed in a standard color and font style (plain packaging)."3 The elaborated guidelines for restrictions on tobacco advertising, promotion and sponsorship, included in FCTC Article 13, also recommend that, "Parties should consider adopting plain packaging requirements to eliminate the effects of advertising or promotion on packaging." ${ }^{4}$ In 2010, Australia became the first country to announce plain packaging regulations.

\section{Tobacco packs as a marketing tool}

Tobacco packaging serves as an integral component of tobacco marketing. The pack provides a direct link between consumers and manufacturers, and is particularly important for consumer products such as cigarettes, which have a high degree of social visibility. ${ }^{5-13}$ Unlike many other consumer products, cigarette packages are displayed each time the product is used and are often left in public view between uses. ${ }^{5,9}$ As a result, both smokers and non-smokers report high levels of exposure to tobacco packaging. ${ }^{9,14}$

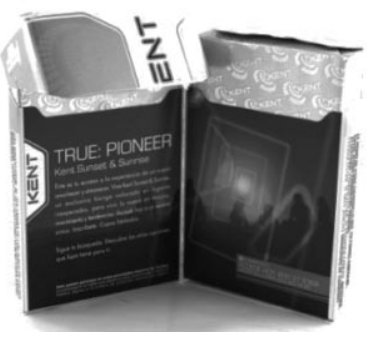

Packaging also serves as a link to other forms of tobacco advertising. 9,15 Packs play a central role in point-of-sale marketing and help to increase the reach of "below the line" marketing activities, such as concerts, and nightclub promotions. ${ }^{7,9,16}$ The package assumes even greater importance in jurisdictions with comprehensive advertising restrictions, ${ }^{10}$ as highlighted by the following quote from a Phillip Morris executive: "Our final communication vehicle with our smoker is the pack itself. In the absence of any other marketing messages, our packaging...is the sole communicator of our brand essence. Put another way-when you don't have anything else-our packaging is our marketing." 17

\section{Brand descriptors}

Tobacco companies have made extensive use of cigarette packages to reassure consumers about the potential risks of their products. ${ }^{18,19}$ A central feature of this strategy has been to use misleading brand descriptors-words and numbers incorporated in the name of a brand. Words such as "light" and "mild" are ostensibly used to denote flavor and taste; however, "light" and "mild" brands have also been promoted in advertisements as less harmful products. 10,19,20 "Light" and "mild" descriptors are typically applied to brands with higher levels of filter ventilation-small holes in cigarette filters. Not only does filter ventilation dilute cigarette smoke to produce deceptively low tar and nicotine numbers under machine testing, but it also produces "lighter" tasting smoke, which reinforces the misleading descriptors on packages. As a result, considerable proportions of adult smokers believe that "light," "mild," and "low tar" cigarette brands lower health risk and are less addictive than "regular" or "full flavor" brands. ${ }^{19,21-26}$ Indeed, many health-concerned smokers report switching to

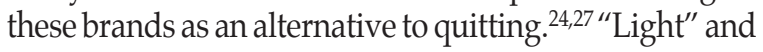
"mild" descriptors may also promote smoking initiation among youth: one study found that U.S. youth believe "light" and "mild" have lower health risk and lower levels of addiction than "regular" brand varieties, similar to adults. ${ }^{28}$ Overall, the synergistic, but subtle effect of brand descriptors, lower emission numbers, and the 
"lighter" tasting smoke have undermined perceptions of risk among smokers, leading many to delay or put off quitting altogether.

To date, more than 50 countries have prohibited the terms "light," "mild," and "low tar," as part of prohibitions on misleading packaging under Article 11 of the WHO Framework Convention on Tobacco Control. However, recent research conducted in Canada, the UK, and Australia suggests that prohibiting "light" and "mild" terms may be insufficient to significantly reduce false beliefs about the risks of different cigarette brands. ${ }^{29}$ Indeed, recent evidence suggests that significant proportions of adult smokers and youth in countries such as the UK continue to report false beliefs about the relative risk of leading cigarette brands. ${ }^{30}$ One potential explanation for these findings is the wide range of other descriptors that remain in use, including words such as "smooth," color descriptors such as "silver" and "blue," as well as "tar" numbers that are incorporated into brand names or printed on the sides of packs. ${ }^{29}$ Studies conducted in the UK and Canada after the removal of "light" and "mild" descriptors suggest that replacement words such as "smooth" have the same misleading effect as light and mild: as many as half of adults and youth in these studies reported that a brand labeled "smooth" would have lower risk than its "regular" counterpart. ${ }^{30,31}$

\section{Pack color and brand imagery}

The persistence of false beliefs may also be due to brand imagery and color., ${ }^{9,10}$ Tobacco industry documents describe this phenomenon: "Lower delivery products tend to be featured in blue packs. Indeed, as one moves down the delivery sector, then the closer to white a pack tends to become. This is because white is generally held to convey a clean healthy association." ${ }^{32}$ Different shades of the same color and the proportion of white space on the package are commonly used to manipulate perceptions of a product's strength and potential risk. Indeed, a number of industry studies have shown that the color and design of the package are effective to the point where they influence sensory perceptions from smoking a cigarette, a process known as "sensory transfer." $10,33,34$ For example, when consumers smoke cigarettes placed in lighter colored packs, they perceive these cigarettes to taste "lighter" and less harsh than the identical cigarettes placed in darker colored packs. Research from other health domains underscores the effect of color on consumer perceptions: the color of pharmaceutical pills, for example, has been shown to influence their effectiveness, presumably through a potent placebo effect. ${ }^{35}$

\section{“Plain" packaging}

The removal of color and other elements of package design-so-called "plain packaging" — has emerged as one regulatory option for reducing potentially misleading package designs. ${ }^{36}$ Plain packaging would standardize the appearance of cigarette packages by requiring the removal of all brand imagery, including corporate logos and trademarks. Packages would display a standard background color and manufacturers would be permitted to print only the brand name in a mandated size, font and position. Other government-mandated information, such as health warnings, would remain.

Plain packaging has several potential effects. First, plain packaging enhances the effectiveness of health warnings by increasing their noticeability, recall, and believability. ${ }^{37-40}$ For example, in one study, New Zealand youth were significantly more likely to recall health warnings when they were presented on plain packs compared to health warnings presented on "normal" branded packages. ${ }^{38}$

Second, plain packaging has the potential to reduce false beliefs about the harmfulness of different
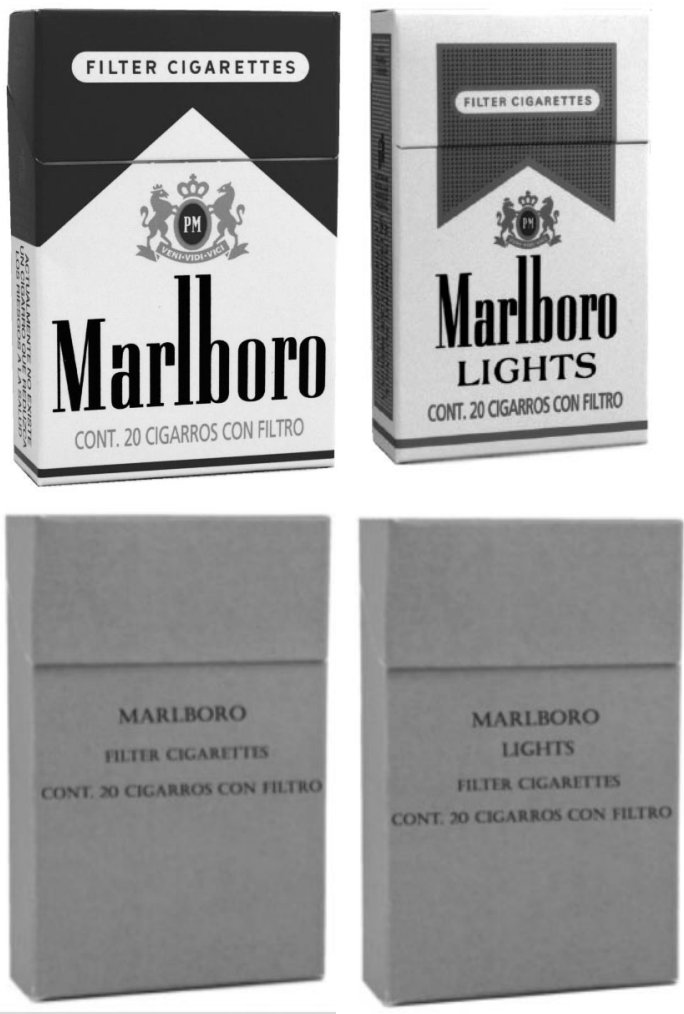

Figure I. Example of "plain" packaging 
cigarette brands. Recent research suggests that substantial proportions of youth and adults hold false beliefs that one brand is less harmful or easier to quit than another. ${ }^{30,31}$ A recent study conducted with adult smokers and youth in the United Kingdom found that, when asked to compare varieties from 8 different cigarette brands, approximately $75 \%$ of adult smokers and youth falsely reported that there were differences in risk between at least one of the varieties. Removing the color and brand imagery from packages significantly reduced these beliefs. ${ }^{30,31}$ Plain packaging has also been shown to reduce beliefs about the link between smoking and weight control. In a recent study conducted among young women in Canada, women who viewed eight female-oriented packs with colors such as pink, were significantly more likely to report that smoking "helps people stay slim" than women who viewed "plain" versions of the same packs. ${ }^{41}$

Third, plain packaging reduces the appeal of smoking. Pack design and the use of brand imagery are particularly effective in targeting youth and younger adults. ${ }^{9,42-44}$ Packaging design is critical to establishing brand appeal and identity among youth, the age at which brand preferences are established. ${ }^{10}$ Research to date suggests that plain packages are less attractive and engaging than normal "branded" packs, and may reduce the appeal of smoking among youth and adults. ${ }^{14,45-49}$ For example, a survey of Canadian youth found that strong majorities "liked" regular packages better than plain packages, and indicated that plain packages are more "boring" and are "uglier" than regular packages. ${ }^{45}$ Approximately one third of respondents also reported that people their age would be less likely to start smoking if all cigarettes were sold in plain packages. A similar study of Canadian and U.S. youth found that plain packages reduced the positive associations with packages and were associated with more negative associations, such as "boring". ${ }^{46}$ Recent research conducted with adult smokers in Australia also found that, "cardboard brown packs with the number of enclosed cigarettes displayed on the front of the pack and featuring only the brand name in small standard font at the bottom of the pack face were rated as significantly less attractive and popular than original branded packs. ${ }^{49}$ Smokers of these plain packs were rated as significantly less trendy / stylish, less sociable/ outgoing and less mature than smokers of the original pack." Similar results have emerged from a recent study conducted among youth and adults in the UK. ${ }^{30}$ Marketing research conducted on behalf of the tobacco industry also suggests that plain packaging reduces some of the appeal of smoking, as the follow quote indicates:

...when we offered them Marlboros at half price--in generic brown boxes --only $21 \%$ were interested, even though we assured them that each package was fresh, had been sealed at the factory and was identical (except for the different packaging) to what they normally bought at their local, tobacconist or cigarette machine.' How to account for the difference? Simple. Smokers put their cigarettes in and out of their pockets 20 to 25 times a day. The package makes a statement. The consumer is expressing how he wants to be seen by others. ${ }^{50}$

Together, these findings suggest that removing the color and brand imagery from packages reduces the appeal of products and may reduce consumption.

\section{References to product design on packages}

Products that are positioned as "low yield" brands often carry images or references to product design on the package. ${ }^{51}$ References to filtration are among the oldest and most common examples of this strategy. For more than 50 years, tobacco companies have communicated filter properties to consumers as tangible evidence of emissions reduction and lower risks. ${ }^{51}$ Indeed, the rise of filtered cigarettes in the U.S. paralleled the rise in health concerns among consumers. As Myron Johnston and W.L. Dunn of Philip Morris stated in 1966, "the illusion of filtration is as important as the fact of filtration." 52 The image at right provides a contemporary example of this packaging strategy

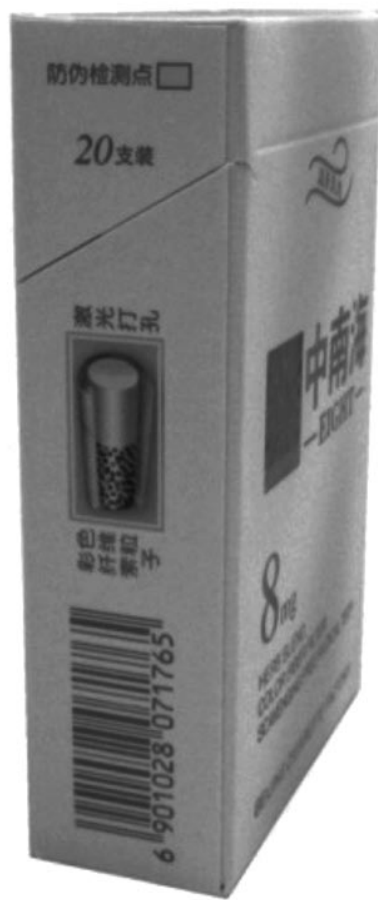


from China, where a leading brand features images of high-tech filters and references to "color cellulose particles." Packages with pictures and references to special cigarette filters such as these were rated by a majority of Canadian smokers as having less tar and lower health risk. ${ }^{31}$ These references to product design and chemical profile on the package are meaningless in terms of actual risk; however, the perception of improved filtration and technology has the potential to falsely reassure consumers.

\section{Standardizing package shape and size}

An additional component of "plain" packaging could include regulations on the shape and size of packages. Tobacco manufactures have released an increasing number of "special edition" packages, many of which have novel shapes and

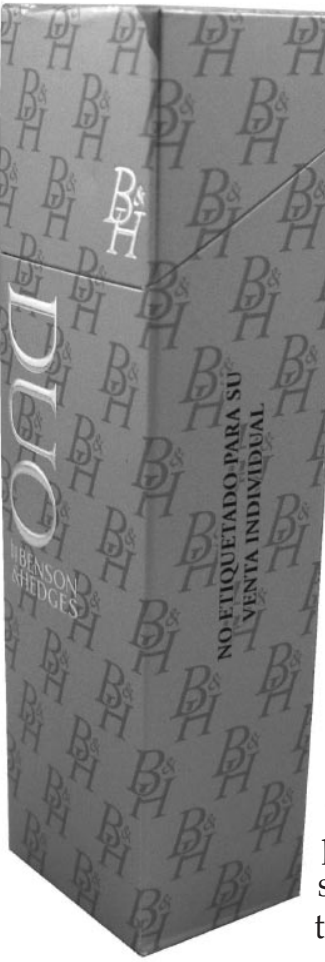
open in different ways. ${ }^{53}$ Novel shapes and sizes may also increase the appeal of cigarette brands and may be particularly engaging to youth. In particular, "slim" packages used to market female brands may promote the widespread belief that smoking is an effective way to stay thin and control weight-an important predictor of tobacco use among girls. ${ }^{41,54,55}$ Different shapes and sizes also have the potential to undermine health warnings on packages. In some cases, packages are so small and narrow that they either warp the health warning pictures or render the text so small as to be unreadable. Additional research on the potential impact of standardizing pack shape and size should be considered a priority.

\section{Industry opposition to plain packaging}

The tobacco industry has taken a strong stance against "plain" packaging regulations. ${ }^{18}$ Philip Morris has characterized plain packaging as "an extreme and dis-

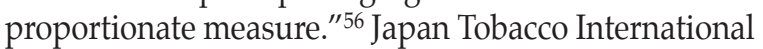
has also indicated its "categorical" opposition to plain packaging, adding that it would be "disproportionate" and may even be "counterproductive" as a tobacco con- trol measure. ${ }^{57}$ British American Tobacco has also stated that, in response to a plain packaging proposal, "we would take every action possible to protect our brands, the rights of our companies to compete as legitimate commercial businesses selling a legal product, and the interests of our shareholders." ${ }^{58}$ The industry's primary arguments against plain packaging relate to insufficient evidence that plain packaging would reduce smoking, and intellectual property rights and issues of international trade. ${ }^{56-58}$ Both the industry and proponents of plain packaging have commissioned legal opinions on this emerging issue.

\section{Summary}

Tobacco packaging and labeling policies have rapidly become among the most prominent and cost-effective tobacco control measures. Although packaging policies have primarily focused on health warnings, there is growing recognition of the importance of packaging as a marketing tool. Standardizing the color and design of tobacco packages is an important component in comprehensive marketing restrictions. The evidence base in support of "plain" and standardized packaging is growing rapidly and consistently points to the potential benefit of plain packaging in terms of increasing the effectiveness of health warnings, reducing false health beliefs about cigarettes, and reducing brand appeal among youth and young adults. A vast body of evidence on the impact of packaging is also contained in internal tobacco industry documents. Tobacco companies have been forced to release millions of pages of internal research reports and other documents as a result of court proceedings in the United States. These documents contain a wealth of information about tobacco industry strategy, research, and consumer perceptions of tobacco packaging. This research consistently demonstrates the influence of color and brand imagery on consumer appeal of products, much of which has yet to be included in published review of industry documents. Research in other consumer domains also provides substantial evidence on the impact of packaging on brand appeal, including among young people. Collectively, these other sources of evidence represent a vast evidence base on the importance of packaging as a marketing tool, and are consistent with the research reviewed in this report on the potential impact of standardizing color and imagery of cigarette packages.

\section{Declaration of conflicts of interest}

I declare that I have no conflicts of interest. 


\section{References}

I. Hammond D.Tobacco labelling and packaging toolkit:A guide to implementing FCTC Article II. November, 2009. [Accessed 19 April 2010]. Available at: www.tobaccolabels.org.

2. WHO:World Health Organization Framework Convention on Tobacco Control [Internet]. Geneva:World Health Organization. [Accessed 19 April 2010]. Available from: http://www.who.int/tobacco/framework/en/. 3. World Health Organization. Guidelines for implementation of Article II of the WHO Framework Convention on Tobacco Control (Packaging and labelling of tobacco products). November, 2008. [Accessed 19 April 2010]. Available at: http://www.who.int/fctc/guidelines/article_II.pdf. 4. World Health Organization. Guidelines for implementation of Article I3 of the WHO Framework Convention on Tobacco Control (Tobacco advertising, promotion and sponsorship). [Accessed 19 April 2010] Available at: http://www.who.int/fctc/guidelines/article_I3.pdf. 5. Shapiro SJ, Perreault WD, McCarthy EJ. Basic Marketing:A global managerial approach. Toronto: McGraw-Hill, 1999.

6. Slade J.The pack as advertisement. Tobacco Control. 1997;6:169-170. 7. Underwood RL, Ozanne J. Is your package an effective communicator? A normative framework for increasing the communicative competence of packaging. Journal of Marketing Communication. 1998;207-20. 8. Palmer A.The Product. Principles of Marketing. Oxford: Oxford University Press/Books; 2000:215-38.

9. Pollay RW.The role of packaging seen through industry documents. Mar 200I. Expert Report prepared for:JTI-Macdonald., Imperial Tobacco Canada Ltd and Rothmans, Benson \& Hedges Inc. v. Attorney General of Canada and Canadian Cancer Society (intervenor). Supreme Court, Province of Quebec, District of Montreal. Defense Exhibit D-II6. 10. Wakefield M, Morley C, Horan JK, Cummings KM. The cigarette pack as image: new evidence from tobacco industry documents. Tobacco Control. 2002 Mar; I (Suppl I):i73-i80.

II. Federal Trade Commission Cigarette Report For 2004 and 2005 [Internet]. 2007. [Accessed 19 April 2010]. Available from: http://www.ftc. gov/reports/tobacco/2007cigarette2004-2005.pdf.

12. Dewhirst T. POP goes the power wall? Taking aim at tobacco promotional strategies utilised at retail. Tobacco Control. 2004;13:209-210 13. Wakefield MA, Terry-McElrath YM, Chaloupka FJ, et al. Tobacco industry marketing at point of purchase after the 1998 MSA billboard advertising ban. Am J Public Health. 2002; 92:937-940.

14. Environics Research Group Limited. The Health effects of tobacco and health warning messages on cigarette packages-Survey of adults and adults smokers:Wave 9 surveys. Ottawa: Health Canada; 2005 Jan. 15. Wakefield M, Letcher T. My pack is cuter than your pack. Tobacco Control. 2002; II:154-156.

16. Carter SM. Going below the line: creating transportable brands for Australia's dark market. Tobacco Control. 2003;12 (Suppl 3):iii87-iii94. 17. Hulit M. Marketing issues corporate affairs conference May 27, 1994-Manila [Internet]. Richmond (VA): Philip Morris. 1994 May. Bates No. 2504015017/5042. [Accessed I9 April 2010]. Available from: http:// legacy.library.ucsf.edu/tid/iga42e00.

18. Freeman B, Chapman S, Rimmer M. The case for the plain packaging of tobacco products. Addiction. 2008; 103(4):580-590.

19. Pollay RW, Dewhirst T. Marketing cigarettes with low machine measured yields In: Smoking and Tobacco Control Monograph I3: Risks Associated with Smoking Cigarettes with Low Machine-Measured Yields of Tar and Nicotine. Bethesda (MD): US Department of Health and Human Services, Public Health Services, National Institutes of Health; National Cancer Institute; 200I:199-233.

20. Pollay RW, Dewhirst T.The dark side of marketing seemingly "Light" cigarettes: successful images and failed fact. Tobacco Control. 2002;I I (Suppl I):il 8-3I.
21. Shiffman S, Pillitteri JL, Burton SL, Rohay JM, Gitchell JG. Smokers' beliefs about "light" and "ultra light" cigarettes. Tobacco Control. 200I; I0(Suppl I):i 17-i23.

22. Ashley MJ, Cohen J, Ferrence R. 'Light' and 'mild' cigarettes: who smokes them? Are they being misled? Canadian Journal of Public Health. 200I;92(6):407-4II.

23. Etter JF, Kozlowski LT, Perneger TV.What smokers believe about light and ultralight cigarettes. Preventative Medicine. 2003;36(I):92-8. 24. Gilpin EA, Emery S,White MM, Pierce JP. Does tobacco industry marketing of 'light' cigarettes give smokers a rationale for postponing quitting? Nicotine \& tobacco research: Official journal of the Society for Research on Nicotine and Tobacco. 2002;4:SI 47-SI 55.

25. Weinstein ND (US Department of Health and Human Services, Public Health Services, National Institutes of Health). Public Understanding of Risk and Reasons for Smoking Low-Yield Products. In: Smoking and Tobacco Control Monograph I3: Risks Associated with Smoking Cigarettes with Low Machine-Measured Yields of Tar and Nicotine. Bethesda (MD): National Cancer Institute; 2001:193-198. 26. Ling PM, Glanz SA. Tobacco industry research on smoking cessation: recapturing young adults and other recent quitters.J Gen Intern Ned. 2004;19(Pt I):419-4426.

27. US Department of Health and Human Services. Risks associated with smoking cigarettes with low machine measured yields of tar and nicotine. Bethesda, MD, USA: US Department of Health and Human Services, Public Health Services, National Institutes of Health; National Cancer Institute, 200I

28. Kropp RY, Halpern-Felsher BL.Adolescents' beliefs about the risks involved in smoking "light" cigarettes. Pediatrics 2004; I I4(4):445-45 I. 29. King B, Borland R.What was "light" and "mild" is now "smooth" and "fine": new labeling of Australian cigarettes. Tobacco Control. 2005; 14(3):2I4-2I5.

30. Hammond D,Arnott D, Dockrell M, Lee A, McNeill A. Cigarette pack design and perceptions of risk among UK adult and youth: evidence in support of plain packaging. European Journal of Public Health 2009; 19(6):63I-637.

31. Hammond D, Parkinson C. The impact of cigarette package design on perceptions of risk. Journal of Public Health 2009; 3 I (3):345-353. 32. Philip Morris, Marketing New Products in a Restrictive Environment [Internet]. 1990 Jun. Bates No. 2044762 I73-2364. [Accessed 19 April 2010]. Available from: http://www.pmdocs.com/getallimg.asp?if=avpidx\&D OCID $=2044762$ I $73 / 2364$.

33. McBride C.A summary of brand imagery studies on Canadian products. Imperial Tobacco Limited Research and Development Division [Internet]. 1987 Sept. Bates No. 570506735-6787. [Accessed 19 April 2010]. Available from: http://legacy.library.ucsf.edu/tid/mdb5 If00/ pdf? search $=22$ a $\% 20$ summary $\% 20$ of $\% 20$ brand $\% 20$ imagery $\% 20$ studies $\% 20$ on $\% 20$ canadian\%20products\%22.

34. Aubin H.Are 'Generic' Packs Cigarettes' Future? 08/e [Internet]. 1989 Nov. Bates range 202338359. [Accessed 19 April 2010]. Available from: http://bat.library.ucsf.edu//tid/per26a99

35. de Craen AJM, Roos PJ, de Vries AL, Kleijnen Jos. Effect of color of drugs: systematic review of perceived effect of drugs and of their effectiveness. BMJ. 1996;3 |3: 1624-1626.

36. Cunningham R, Kyle K. The case for plain packaging. Tobacco Control. 1995;4:80-86.

37. Goldberg ME, Liefeld J, Madill J,Vredenburg H. The effect of plain packaging on response to health warnings. American Journal of Public Health. 1999;89:1434-1435.

38. Beede P, Lawson R. The effect of plain packages on the perception of cigarette health warnings. Public Health 1992;106(4):315-322.

39. Goldberg ME, Kindra G, Lefebvre J, Liefeld J, Madill-Marshall J, Martohardjono N, et al. When packages can't speak: Possible impact of plain and generic packaging of tobacco products. Expert Panel Report. Ottawa (Canada): Health Canada; 1995. 
40. Hammond D. Potentially misleading information and plain packaging: New Canadian findings. World Conference on Tobacco Health; 2009 March 9; Mumbai, India.

4I. Doxey JR, Hammond D. Deadly in pink:The impact of cigarette packaging on brand appeal, beliefs about smoking, and risk perceptions among young women. [Accessed 19 April 2010]. Available at: http:// uwspace.uwaterloo.ca/bitstream/I00 I2/4823/I/Doxey_Juliana.pdf. 42. DiFranza JR, Eddy JJ, Brown LF, et al. Tobacco acquisition and cigarette brand selection among the youth. Tob Control. 1994;3:334-338.

43. Cummings KM, Morley C, Horan J, et al. Marketing to America's youth: evidence from corporate documents. Tob Control 2002; I (suppl I):i5-il7. 44. Chapman S.Australia: British American Tobacco "addresses" youth smoking. Tobacco Control 2007; 16:2-3.

45. Northrup D, Pollard J. Plain Packaging of Cigarettes, Event Marketing to Advertise Smoking and other Tobacco Issues: A Survey of Grade Seven and Grade Nine Ontario Students. Toronto:York University; 1995. 46. Germain B,Wakefield MA, Durkin SJ.Adolescents' Perceptions of Cigarette Brand Image: Does Plain Packaging Make a Difference? Journal of Adolescent Health 2009: I-8.

47. Rootman I, Flay B.A study on youth smoking plain packaging, health warnings, event marketing, and price reductions key findings. Toronto: University of Toronto, Centre for Health Promotion, 1995. 48. Trachtenberg JA. Here's one tough cowboy. Forbes. $1987 \mathrm{Feb}$ 9;139:108.

49. Wakefield MA, Germain D, Durkin SJ. How does increasingly plainer cigarette packaging influence adult smokers' perceptions about brand image? An experimental study. Tobacco Control 2008; 17:416-42I.

50.A. Trachtenberg. Here's one tough cowboy. Forbes 1987; 139: 108. 9 February 1987.

5I. Pollay RW, Dewhirst T. Marketing cigarettes with low machine measured yields In: Smoking and Tobacco Control Monograph I3: Risks
Associated with Smoking Cigarettes with Low Machine-Measured Yields of Tar and Nicotine. US Department of Health and Human Services. Bethesda, MD: US Department of Health and Human Services, Public Health Services, National Institutes of Health; National Cancer Institute, 200I:199-233.

52. Dunn WL, Johnston ME. Market potential of a health cigarette. Jun 1966. Bates No. 1000338644/8653. [Accessed 19 April 2010]. Available at: http://tobaccodocuments.org/landman//000338644-867l.html.

53. Neuber D. New shapes, new feel for cigarette packs. Tobacco Journal 2009; July 9.

54. Carpenter CM,Wayne GF, Connolly GN. Designing cigarettes for women: New findings from the tobacco industry documents. Addiction 2005; 100:837-85|.

55. U.S Surgeon General. Patterns of Tobacco Use Among Women and Girls. In: Surgeon General's Report-Women and Smoking 200 I:19-176. 56. Philip Morris. Philip Morris Limited's Response to the Department of Health's Consultation on the Future of Tobacco Control.

Sept, 2008. [Accessed 19 April 2010]. Available at: http://www. philipmorrisinternational.com/global/downloads/OBE/PML_Submission_ to_DH_consultation_on_future_of_tobacco_control.pdf. 57. Japan Tobacco International. Response to the UK Department of Health's consultation on the future of tobacco control, September 2008. [Accessed 19 April 2010]. Available at: http://www.jti.com/file.axd?pointer

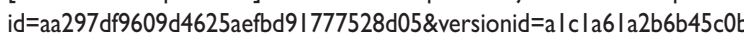
e60540466664e9e.

58. British American Tobacco. Plain Packaging. 30 january 2010. [Accessed 19 April 2010]. Available at: http://www.bat.com/group/sites/uk_3mnfen. nsf/vwPagesWebLive/DO7J7DCZ? opendocument\&SKN=3. 